\title{
ResearchArticle
}

\section{Variability and character association in cowpea using Bradyrhizobium strain}

\author{
S.P. SHARMA, P.P. SHARMA, S.R. NEHRA AND C.L. KHATIK
}

\begin{abstract}
SUMMARY
A field experiment was carried out using twenty genotypes of cowpea [Vigna unguiculata (L.) walp] at Rajasthan College of Agriculture, Udaipur during 2008-09 treated with two Bradyrhizobium strains. Association studies revealed that seed yield per plant showed significant positive co-rrelation with pods per plant in all the environments, biological yield $\left(\mathrm{E}_{1}\right.$ and $\left.\mathrm{E}_{2}\right)$, harvest index $\left(\mathrm{E}_{1}\right.$ and $\mathrm{E}_{3}$ ), protein content $\left(\mathrm{E}_{3}\right)$, days to maturity, nodule fresh weight and nitrogen content in $\left(\mathrm{E}_{3}\right)$, most of these characters were also mutually correlated. Path analysis studies for seed yield revealed direct and indirect contribution of biological yield, harvest index, branches per plant, plant height and number of nodules $\left(\mathrm{E}_{1}\right)$, pods per plant, nodule fresh weight, protein content and nodule dry weight $\left(\mathrm{E}_{2}\right)$, nodule dry weight, branches per plant, protein content and plant height $\left(\mathrm{E}_{3}\right)$. While the protein content revealed direct as well as indirect contribution of biological yield, number of nodules, harvest index, 100 seed weight and nodule fresh weight $\left(\mathrm{E}_{1}\right)$, number of nodules, seed yield per plant, leghaemoglobin content and nitrogen content in $\left(\mathrm{E}_{2}\right)$, seed yield per plant, harvest index, number of nodules and nodule fresh weight in $\left(\mathrm{E}_{3}\right)$.
\end{abstract}

Key Words : Cowpea, Seed yield, Characters, Genotypes

How to cite this article : Sharma, S.P., Sharma, P.P., Nehra, S.R. and Khatik, C.L. (2015). Variability and character association in cowpea using Bradyrhizobium strain. Internat. J. Plant Sci., 10 (1): 43-48.

Article chronicle : Received : 19.07.2014; Revised : 18.11.2014; Accepted : 01.12.2014

\section{MEMBERS OF THE RESEARCH FORUM}

Author to be contacted :

C.L. KHATIK, Department of Plant Breeding and Genetics, Rajasthan College of Agriculture, Maharana Pratap University of Agriculture and Technology, UDAIPUR (RAJASTHAN) INDIA

Address of the Co-authors:

S.P. SHARMA,P.P. SHARMA AND S.R. NEHRA, Department of Plant Breeding and Genetics, Rajasthan College of Agriculture, Maharana Pratap University of Agriculture and Technology, UDAIPUR (RAJASTHAN) INDIA 